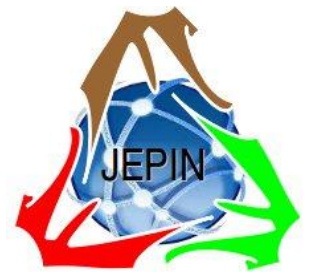

\title{
Leap Motion Controller Game Sebagai Alat Bantu Terapi Rehabilitasi Otot Tangan
}

\author{
Restu Rakhmawati ${ }^{\# 1}$, Helmi Roichatul Jannah ${ }^{* 2}$

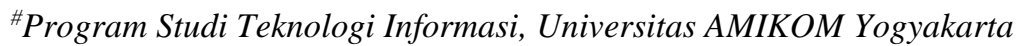 \\ Jln. Ringroad Utara, Condongcatur, Sleman, Yogyakarta \\ ${ }^{1}$ resturakhma@amikom.ac.id \\ *Magister Informatika, Universitas Islam Indonesia \\ Jln. Kaliurang km 14,5, Sleman, Yogyakarta \\ 217917209@uii.ac.id
}

\begin{abstract}
Abstrak - Salah satu bagian tubuh yang rawan mengalami cedera adalah tangan. Cedera tangan umumnya disebabkan oleh kecelakaan yang tidak disengaja ataupun dampak dari beberapa penyakit seperti parkinson dan stroke. Cedera otot tangan memerlukan proses penyembuhan secara terapi dan pemulihan dengan rehabilitasi. Terapi dan rehabilitasi otot tangan sangat bergantung pada gerakan olahraga rutin pada pasien dengan rekomendasi dari dokter. Namun terdapat beberapa kendala yang dihadapi oleh pasien yang memerlukan terapi ini. Pertama, proses terapi rehabilitasi otot tangan memerlukan waktu yang panjang sehingga membuat pasien merasa bosan. Kedua, pasien mendapatkan instruksi dari dokter untuk melakukan gerakan yang melatih otot tangan seperti mengepal-kepalkan tangan, mengambil benda-benda di rumah dengan menggunakan tangan. Pasien memerlukan alat bantu yang dapat mempermudah mereka untuk melakukan gerakan terapi secara rutin sesuai dengan perkembangan kondisi tangan mereka. Leap motion controller akan digunakan sebagai perangkat masukan (input) pada alat bantu terapi yang akan dikembangkan. Permainan tersebut dapat dimainkan oleh pemain dengan menggunakan leap motion controller. Permainan didesain berdasarkan rekomendasi gerakan rehabilitasi oleh dokter. Penelitian ini bertujuan untuk mengembangkan teknologi yang dapat membantu proses terapi rehabilitasi pasien cedera otot tangan. Alat bantu terapi yang dikembangan akan menerapkan gamifikasi untuk membuat proses terapi lebih mudah dan menyenangkan bagi pasien.
\end{abstract}

Kata kunci - Terapi, Otot Tangan, Rehabilitasi, Game, Leap Motion Controller

\section{Pendahuluan}

Salah satu bagian tubuh yang rawan mengalami cedera adalah tangan. Cedera tangan umumnya disebabkan oleh kecelakaan yang tidak disengaja ataupun dampak dari beberapa penyakit seperti parkinson dan stroke. Cedera otot tangan memerlukan proses penyembuhan secara paliatif dan rehabilitatif[1]. Terapi dan rehabilitasi otot tangan sangat bergantung pada gerakan olahraga rutin pada pasien dengan rekomendasi dari dokter. Latihan gerak yang rutin dan tepat dapat membantu terapi dan rehabilitasi pasien[2].
Latihan gerakan terapi tangan yang dapat dilakukan oleh pasien cedera tangan diantaranya adalah gerakan menggenggam, gerakan mengambil benda dengan jari, gerakan menahan benda dengan tangan, dan gerakangerakan lain sesuai rekomendasi dari dokter[3].

Namun terdapat beberapa kendala yang dihadapi oleh pasien yang memerlukan terapi ini. Pertama, proses terapi rehabilitasi otot tangan memerlukan waktu yang panjang sehingga membuat pasien merasa bosan. Untuk meminimalisir rasa bosan pada pasien, diperlukan adanya metode yang mampu mengadaptasi proses terapi ke dalam sebuah permainan[4]. Efektifitas terapi harus lebih intens dan berulang pada gerakan-gerakan yang fungsional. Kedua, pasien mendapatkan instruksi dari dokter untuk melakukan gerakan yang melatih otot tangan seperti mengepal-kepalkan tangan, mengambil benda-benda di rumah dengan menggunakan tangan. Pasien cenderung merasa kesulitan untuk terus melakukan gerakan tersebut berulang kali tanpa instruksi dari dokter ketika berada di rumah[1].

Pasien memerlukan alat bantu yang dapat mempermudah mereka untuk melakukan gerakan terapi secara rutin sesuai dengan perkembangan kondisi tangan mereka. Penelitian ini bertujuan untuk mengembangkan teknologi yang dapat membantu proses terapi rehabilitasi pasien cedera otot tangan. Alat bantu terapi yang dikembangan akan menerapkan gamifikasi untuk membuat proses terapi lebih mudah dan menyenangkan bagi pasien. Pada penelitian ini alat bantu yang dikembangkan berupa game non-immersive yang dikendalikan dengan menggunakan leap motion controller. Alat bantu pada penelitian ini akan dikembangkan untuk menyelesaikan masalah-masalah yang dialami oleh pasien rehabilitasi otot tangan.

Berdasarkan kendala-kendala dan kebutuhan pasien terhadap proses terapi rehabilitasi otot tangan, maka ada dua hal yang harus diperhatikan dalam pengembangan alat bantu terapi tersebut. Pertama, alat bantu terapi yang akan dibangun harus mampu mengukur kondisi otot tangan 
pasien sebelum pasien memulai proses terapi. Kedua, gerakan rehabilitasi harus disesuaikan dengan kondisi otot tangan pasien. Untuk mengukur kondisi otot tangan pasien diperlukan adanya sensor yang mampu menangkap gerakan tangan pasien. Perangkat yang dapat digunakan untuk menangkap sensor gerakan tangan tersebut adalah leap motion controller. Leap motion controller akan digunakan sebagai perangkat masukan (input) pada alat bantu terapi yang akan dikembangkan. Permainan tersebut dapat dimainkan oleh pemain dengan menggunakan leap motion controller. Permainan didesain berdasarkan rekomendasi gerakan rehabilitasi oleh dokter.

\section{TINJAUAN PUSTAKA DAN TEORI}

\section{A. Tinjauan Pustaka}

Pada penelitian ini dilakukan tinjauan pustaka yang bertujuan untuk mencari penelitian-penelitian yang membahas tentang teknologi rehabilitasi otot tangan. Penelitian tentang pengembangan teknologi untuk alat bantu rehabilitasi pasien tangan telah dikembangkan oleh beberapa peneliti. Hal ini menunjukkan bahwa bidang tersebut memang menarik untuk diteliti.

Adanya kebutuhan dalam mengembangkan alat bantu terapi rehabilitasi tangan yang didukung teknologi membuat banyak peneliti tertarik untuk membahas masalah ini. Proses pencarian penelitian untuk tinjauan pustaka pada penelitian ini dengan mencari penelitian-penelitian yang membahas mengenai teknologi sebagai alat bantu rehabilitasi. Hasil dari tinjauan Pustaka ditunjukan pada tabel 1 .

TABEL I

TINJAUAN PUSTAKA

\begin{tabular}{|l|l|l|l|}
\hline \multicolumn{1}{|c|}{ Author } & Year & \multicolumn{1}{|c|}{ Topics } & Technology \\
\hline Mckenzie & 2014 & $\begin{array}{l}\text { Hand } \\
\text { rehabilitation }\end{array}$ & $\begin{array}{l}\text { Leap motion } \\
\text { controller } \\
\text { game }\end{array}$ \\
\hline Patrick, dkk. & 2015 & $\begin{array}{l}\text { Hand } \\
\text { rehabilitation }\end{array}$ & $\begin{array}{l}\text { Leap motion } \\
\text { controller } \\
\text { game }\end{array}$ \\
\hline $\begin{array}{l}\text { Manolova \& } \\
\text { Neshov }\end{array}$ & 2016 & $\begin{array}{l}\text { Hand } \\
\text { rehabilitation }\end{array}$ & $\begin{array}{l}\text { Leap motion } \\
\text { controller } \\
\text { game }\end{array}$ \\
\hline Daldiri,dkk. & 2017 & $\begin{array}{l}\text { Hand } \\
\text { rehabilitation }\end{array}$ & $\begin{array}{l}\text { Leap motion } \\
\text { controller } \\
\text { game }\end{array}$ \\
\hline Afyouni, dkk & 2017 & $\begin{array}{l}\text { Hand } \\
\text { rehabilitation }\end{array}$ & $\begin{array}{l}\text { Leap motion } \\
\text { controller } \\
\text { game }\end{array}$ \\
\hline Kaji\&Sugano & 2017 & $\begin{array}{l}\text { Hand } \\
\text { rehabilitation }\end{array}$ & $\begin{array}{l}\text { Leap motion } \\
\text { controller } \\
\text { game }\end{array}$ \\
\hline $\begin{array}{l}\text { Alimanova, } \\
\text { dkk }\end{array}$ & 2017 & $\begin{array}{l}\text { Hand } \\
\text { rehabilitation }\end{array}$ & $\begin{array}{l}\text { Leap motion } \\
\text { controller } \\
\text { game }\end{array}$ \\
\hline Ona, dkk & 2018 & $\begin{array}{l}\text { Upper Limb } \\
\text { rehabilitation }\end{array}$ & $\begin{array}{l}\text { Leap motion } \\
\text { controller }\end{array}$ \\
\hline Lee, dkk & 2019 & Bradykinesia & $\begin{array}{l}\text { Leap motion } \\
\text { controller }\end{array}$ \\
\hline
\end{tabular}

Hasil dari proses pencarian tinjauan pustaka menghasilkan sembilan penelitian yang membahas teknologi sebagai alat bantu rehabilitasi. Hasil analisis topik penelitian yang ditunjukkan pada tabel 2, penelitian [1], [4]-[9] membahas mengenai rehabilitasi otot tangan. Sedangkan penelitian [3] membahas mengenai rehabilitasi anggota tubuh bagian atas. Penelitian [10] membahas tentang bradikinesia. Rehabilitasi tangan dapat dilakukan oleh pasien yang memiliki cedera otot tangan karena kelelahan, kecelakaan, atau gejala dan efek samping dari penyakit tertentu. Penyakit yang menyerang otot tangan diantaranya adalah stroke, cerebral palsy, dan parkinson[8]. Berdasarkan hasil analisis tersebut maka tren penelitian mengarah pada terapi rehabilitasi tangan.

\section{B. Teknologi Rehabilitasi Otot Tangan}

Berdasarkan hasil analisis pada tabel 1 menunjukkan bahwa semua penelitian menggunakan leap motion controller game sebagai teknologi alat bantu terapi. Dengan demikian menunjukkan bahwa leap motion controller game direkomendasikan dalam pengembangan alat bantu terapi yang memerlukan sensor gerakan tangan.

Leap motion controller(LMC) adalah alat untuk mendeteksi sensor tangan. Alat ini dapat mendeteksi gerakan tangan mulai dari siku hingga ujung jari[11]. LMC dapat digunakan sebagai teknologi untuk rehabilitasi otot tangan karena mampu mendeteksi tremor pada pasien yang mengalami gejala gangguan otot tangan seperti pasien stroke dan parkinson[12].

Pada implementasinya LMC diintegrasikan dengan software lain yang mendukung salah satunya adalah Unity3D. Hand environment untuk terapi dapat dikembangkan dengan mengintegrasikan Unity3D dengan LMC[13]. Integrasi antara Unity3D dengan LMC untuk teknologi terapi dapat berupa game[14]. Game yang dikembangkan akan dirancang khusus sesuai dengan tahapan terapi pasien. Pasien akan mengalami pengalaman yang sama bahkan lebih menarik Ketika menggunakan game sebagai media terapi[3].

Berdasarkan hasil tersebut maka penelitian ini akan mengembangkan alat bantu terapi untuk rehabilitasi otot tangan dengan menggunakan media berupa game. Game tersebut akan dikembangkan dengan dukungan LMC sebagai alat input sensor tangan pada game.

\section{Terapi Rehabilitasi Otot Tangan}

Terapi rehabilitasi otot tangan biasa dilakukan oleh pasien yang menderita stroke atau Parkinson. Gerakan terapi rehabilitasi otot tangan disusun dalam Terapi Fisik Anggota Gerak Tangan Pascastroke sesuai dengan kebutuhan[7]. Gerak tangan terapi rehabilitasi otot tangan diantaranya:

1. Gerakan mengangkat tangan

2. Gerakan menggeser tangan dan memutar pergelangan tangan

3. Gerakan menangkupkan jari-jari tangan 


\section{Metodologi PENELITIAN}

\section{A. Skema Alur Penelitian}

Penelitian ini dilaksanakan sesuai dengan skema alur penelitian yang ditunjukkan pada gambar 1 .

Penelitian akan dimulai dengan mengidentifikasi masalah dengan studi literatur. Studi literatur dilakukan dengan mencari penelitian dengan topik yang akan diteliti. Hasil dari identifikasi masalah kemudian dianalisis untuk kebutuhan perancangan game. Setelah dilakukan analisis kebutuhan proses penelitian dilanjutkan ke tahap implementasi konsep terapi rehabilitasi otot tangan ke dalam perancangan game.

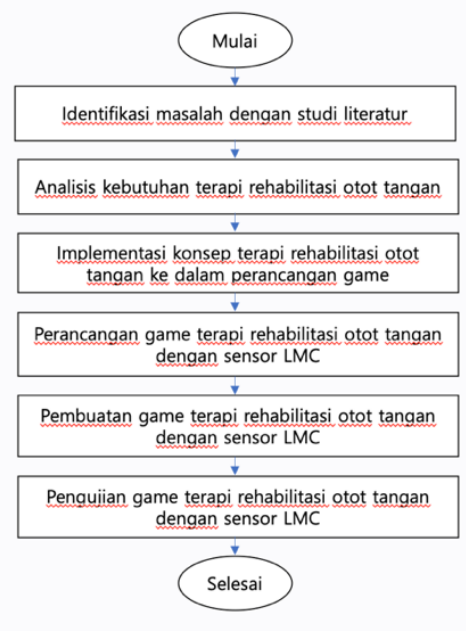

Gambar 1. Langkah penelitian

Proses dilanjutkan dengan merancang game terapi rehabilitasi otot tangan dengan sensor LMC sebagai kontrolnya. Tahapan selanjutnya adalah memulai pembuatan game terapi dengan menggunakan game engine unity 3D. Setelah game yang dirancang selesai dibuat, tahapan selanjutnya adalah menguji apakah game yang dihasilkan mampu berfungsi dan berjalan sesuai dengan kebutuhan rancangan atau tidak. Setelah semua proses penelitian diselesaikan, maka dapat ditarik kesimpulan dan saran untuk perbaikan penelitian di masa mendatang.

\section{B. Identifikasi masalah}

Penelitian diawali dengan mencari studi literatur untuk mengidentifikasi masalah yang terkait dengan terapi rehabilitasi otot tangan. Berdasarkan hasil studi literatur yang dijelaskan pada bagian tinjauan Pustaka, ditemukan beberapa hal yang harus diperhatikan. Hal yang harus diperhatikan adalah diperlukan adanya teknologi yang dapat membantu proses terapi. Salah satu teknologi yang dapat membantu proses terapi adalah leap motion controller (LMC) yang dapat mengidentifikasi sensor gerakan tangan pasien.

LMC akan dikombinasikan dengan game yang dikembangkan menjadi alat bantu terapi untuk terapi rehabilitasi otot tangan. Dalam proses terapi otot tangan, yang diperhatikan adalah aktivitas berupa gerakan tangan yang tepat dan berulang. gerakan tangan tersebut bisa dilakukan pasien dengan bantuan game terapi yang dikembangkan.

\section{Analisis kebutuhan}

Setelah melakukan identifikasi masalah pada penelitian ini, tahapan selanjutnya adalah menganalisis kebutuhan untuk menemukan solusi masalah tersebut. Masalah yang ditemukan adalah adanya kebutuhan teknologi untuk membantu proses terapi rehabilitasi otot tangan. Solusi yang akan diberikan adalah dengan membangun teknologi alat bantu terapi untuk rehabilitasi otot tangan berupa game yang menggunakan sensor LMC yang bisa mengidentifikasi gerakan tangan pasien.

Untuk mengembangkan solusi tersebut maka diperlukan adanya analisis kebutuhan dari game tersebut. Adapun kebutuhan-kebutuhan yang dianalisis meliputi: analisis kebutuhan perangkat lunak dan analisis kebutuhan materi.

Analisis kebutuhan perangkat lunak bertujuan untuk mengetahui spesifikasi yang diperlukan untuk membangun game. Alat bantu terapi yang akan dikembangkan berupa game dengan piranti masukan berupa sensor tangan yaitu Leap Motion Controller yang ditunjukkan pada gambar 2. Leap Motion Controller(LMC) adalah alat yang mampu mendeteksi gerakan tangan. Adapun kebutuhan untuk menjalankan perangkat LMC yaitu sistem operasi windows minimal windows 7 64-bit dan Leap Motion Orion versi minimal 4.0.0. Kebutuhan game engine yang sesuai untuk LMC yaitu Unity3d versi 2017.1 - 2020.1.

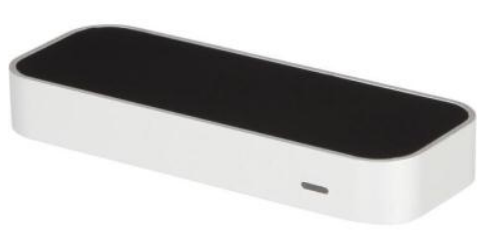

Gambar 2. Leap motion controller

Analisis kebutuhan materi dilakukan untuk mengidentifikasi kebutuhan materi yang akan diberikan dalam game. Ada beberapa faktor yang harus diperhatikan dalam mengembangkan game alat bantu terapi rehabilitasi otot tangan. Game yang akan dikembangkan sebagai alat bantu terapi bertujuan untuk memberikan alternatif media terapi yang lebih mudah dan menyenangkan bagi pasien. Oleh karena itu diperlukan penyesuaian aktivitas dalam game yang sesuai dengan tahapan terapi yang dilakukan pasien.

Rancangan gerakan yang akan dikembangkan merujuk pada panduan Terapi Fisik Anggota Gerak Tangan:

1. Gerakan mengangkat tangan

2. Gerakan menggeser tangan dan memutar pergelangan tangan

3. Gerakan menangkupkan jari-jari tangan 


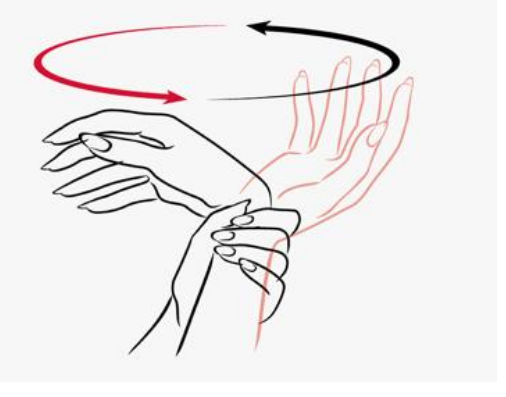

Gambar 3. Gerakan memutar pergelangan tangan

\section{Perancangan}

Perancangan game pada penelitian ini menggunakan MDA Framework[15]. MDA Framework sesuai dengan tujuan dari pembuatan game ini yaitu sebagai alat bantu terapi yang menyenangkan bagi pasien. Dalam MDA framework terdapat 3 komponen yang digunakan dalam game, yaitu:

1. Mechanics adalah komponen aturan dalam sebuah game. Komponen mechanics dalam game diwujudkan dalam beberapa bagian game sebagai berikut:
a. Genre
Genre game ini adalah simulasi. Game ini memungkinkan pasien untuk melakukan simulasi terapi
b. Goal
Goal atau tujuan dari game ini adalah pasien dapat melakukan terapi sesuai dengan instruksi dokter dan cara yang lebih menarik
c. Platform
Platform yang digunakan dalam game ini adalah desktop.

\section{d. Level}
Pada game ini terdapat 3 level atau tahapan. Tahap 1 adalah melatih gerakan menaik- turunkan tangan. Tahap 2 adalah melatih gerakan menggeser tangan dan memutar pergelangan tangan. Tahap 3 adalah melatih otot tangan pasien untuk menangkupkan tangan.

2. Dynamics adalah komponen yang mengatur interaksi pemain dengan game. Dynamics dalam game diwujudkan menjadi sebagai berikut:

\section{a. Control}

Kontrol pemain dalam game ini yaitu dengan menggunakan sensor Leap Motion Controller (LMC).

\section{b. Challenge}

Challenge atau tantangan dalam game ini yaitu pasien harus menyelesaikan instruksi dari setiap tahapan supaya dapat melakukan terapi.

c. Rules

Rules pada game ini adalah pemain harus meletakkan tangan sesuai dengan posisi yang bisa dideteksi oleh sensor.
3. Aesthetics adalah komponen yang didapatkan oleh pemain dalam game. Aesthetics dalam game diwujudkan dalam komponen sebagai berikut:

\section{a. Sensation}

Pemain mendapatkan respon sensasi yang baru saat proses terapi dengan game ini karena menggunakan alat bantu terapi yang menyenangkan.

b. Discovery

Pemain dapat menggali kemampuan gerakan otot tangannya masing-masing dengan mencoba berinteraksi dengan objek yang ada pada game.

\section{E. Pengembangan}

Game pada penelitian ini dikembangkan dengan menggunakan software Unity3D versi 2020.1. Pengembangan game diawali dengan membuat setting sensor LMC yang sesuai dengan kebutuhan game. Setelah melalui beberapa percobaan dihasilkan tatanan sensor, posisi tangan pemain, dan posisi komputer seperti pada gambar 4

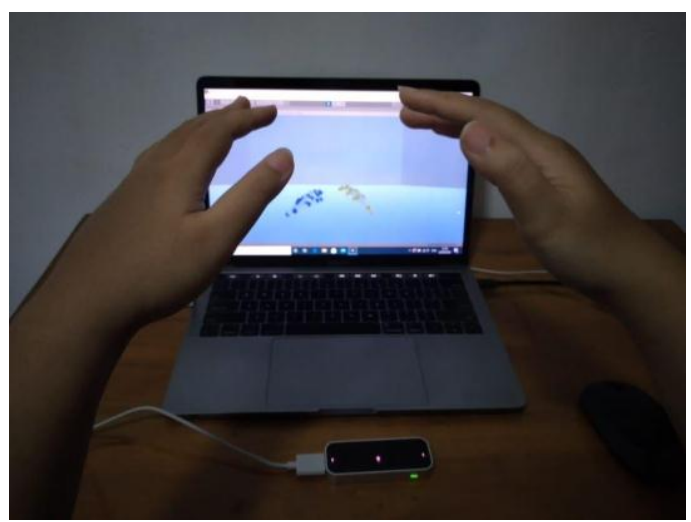

Gambar 4. Susunan sensor LMC dan tangan pemain

Sensor LMC diletakkan di depan komputer. Kemudian pemain meletakkan tangannya tepat di atas sensor LMC. Sensor LMC mampu mendeteksi tangan pemain dengan jarak 10-15 cm tepat di atas sensor.

Setelah sensor mampu mendeteksi tangan, maka dilanjutkan dengan mengintegrasikan sensor LMC dengan software Unity3D seperti pada gambar 5.

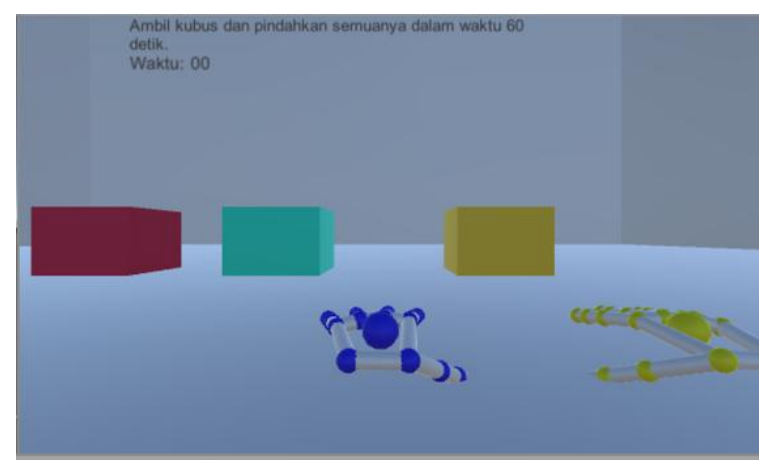

Gambar 5. Integrasi sensor LMC pada Unity3D 
Tahap selanjutnya ada;lah memulai mengembangkan game dengan software Unity3D. Proses pengembangan game dengan Unity3D dapat dilihat pada gambar 6 . Gerakan-gerakan terapi yang telah dirancang kemudian diimplementasikan menjadi mekanika dan gameplay game. Tahapan pada terapi diimplementasikan menjadi level dalam game. Setelah pengembangan game selesai maka dihasilkan game yang telah siap untuk diuji.

\section{HASIL DAN PEMBAHASAN}

A. Hasil

Game yang sudah dikembangkan merujuk pada tahapan terapi. Terdapat 3 level pada game ini. Tampilan hasil game yang dikembangkan ditunjukkan pada gambar 4, 5, dan 6.

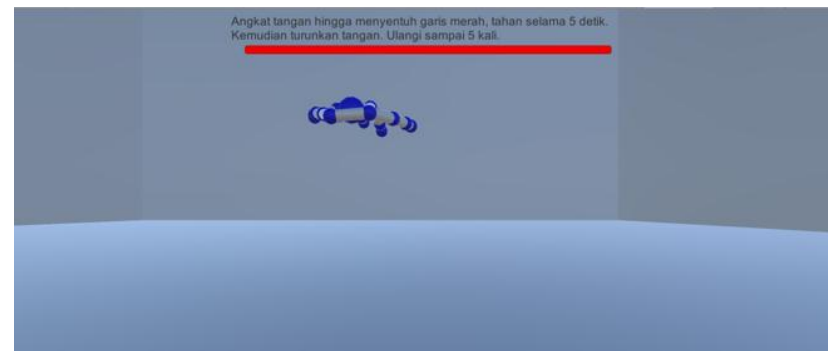

Gambar 6. Tampilan game tahap 1

Pada tahap pertama pemain harus mengangkat tangan sampai menyentuh garis berwarna merah selama 5 detik dan mengulangi hingga 5 kali. Gerakan ini bertujuan untuk menguatkan ketahanan otot tangan pasien.

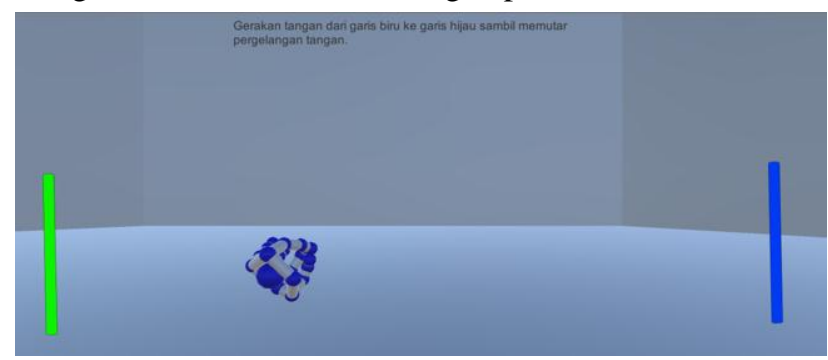

Gambar 7. Tampilan game tahap 2

Pada tahap kedua, pemain harus menggeser tangannya dari garis biru ke hijau sambil memutar pergelangan tangan. Gerakan ini bertujuan untuk melatih pasien untuk menggerakkan pergelangan tangannya.

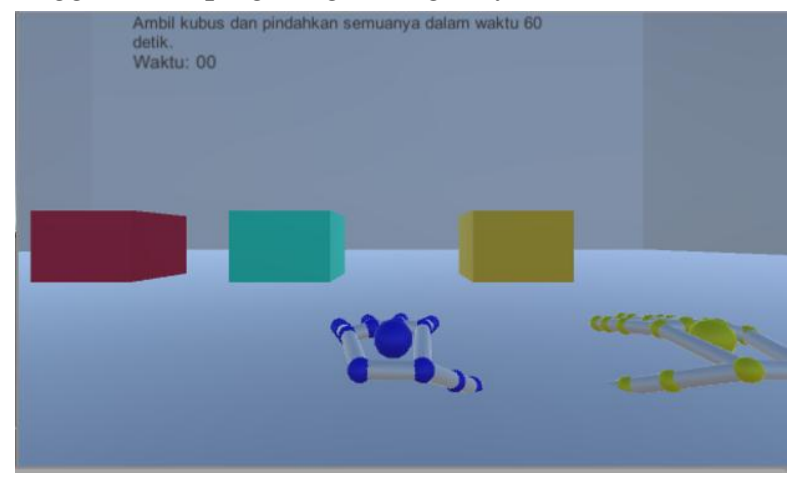

Gambar 8. Tampilan game tahap 3
Pada tahap ketiga, pemain harus mengambil kubus dan memindahkannya ke poisisi yang lain. Gerakan ini bertujuan untuk melatih pasien memperkuat koordinasi antara jari-jari tangan.

\section{B. Pembahasan}

Tahap terakhir adalah pengujian game. Pengujian game menggunakan black box testing. Pengujian ini menguji apakah fungsi-fungsi dalam game mampu berjalan dengan baik atau tidak. Pengujian black box dibagi menjadi pengujian sensitivitas sensor dan pengujian interaksi pemain dengan game. Berikut hasil pengujian black box testing pada game yang dikembangkan:

1) Pengujian sensitivitas sensor: Pengujian sensitivitas sensor dilakukan dengan skenario pengujian yang dijelaskan pada tabel II. Hasil dari pengujian menunjukkan bahwa sensor dapat mendeteksi tangan pemain dan dapat mendeteksi gerakan pemain,

TABEL II

Pengujian SENSITIVITAS SENSOR

\begin{tabular}{|c|c|c|c|}
\hline $\begin{array}{l}\text { Aktivitas } \\
\text { pengujian }\end{array}$ & $\begin{array}{l}\text { Respon } \\
\text { yang } \\
\text { diharapkan }\end{array}$ & $\begin{array}{l}\text { Hasil } \\
\text { pengujian }\end{array}$ & Kesimpulan \\
\hline $\begin{array}{l}\text { Meletakkan } \\
\text { kedua tangan } \\
\text { di atas sensor }\end{array}$ & $\begin{array}{l}\text { Muncul } \\
\text { kedua objek } \\
\text { tangan pada } \\
\text { game }\end{array}$ & $\begin{array}{l}\text { Kedua } \\
\text { tangan } \\
\text { terdeteksi } \\
\text { oleh game }\end{array}$ & valid \\
\hline $\begin{array}{l}\text { Meletakkan } \\
\text { tangan kanan } \\
\text { di atas sensor }\end{array}$ & $\begin{array}{l}\text { Muncul objek } \\
\text { tangan kanan } \\
\text { pada game }\end{array}$ & $\begin{array}{l}\text { Game } \\
\text { mampu } \\
\text { mendeteksi } \\
\text { tangan } \\
\text { kanan }\end{array}$ & Valid \\
\hline $\begin{array}{l}\text { Meletakkan } \\
\text { tangan kiri di } \\
\text { atas sensor }\end{array}$ & $\begin{array}{l}\text { Muncul objek } \\
\text { tangan kiri } \\
\text { pada game }\end{array}$ & $\begin{array}{l}\text { Game } \\
\text { mampu } \\
\text { mendeteksi } \\
\text { tangan kiri }\end{array}$ & Valid \\
\hline $\begin{array}{l}\text { Menggerakkan } \\
\text { tangan ke atas } \\
\text { dan ke bawah }\end{array}$ & $\begin{array}{l}\text { Objek tangan } \\
\text { pada game } \\
\text { mengikuti } \\
\text { gerakan } \\
\text { tangan } \\
\text { pemain }\end{array}$ & $\begin{array}{l}\text { Objek } \\
\text { tangan pada } \\
\text { game } \\
\text { mampu } \\
\text { mengikuti } \\
\text { gerakan } \\
\text { tangan } \\
\text { pemain }\end{array}$ & Valid \\
\hline $\begin{array}{l}\text { Menggeser } \\
\text { tangan dari } \\
\text { arah kiri ke } \\
\text { kanan dan } \\
\text { sebaliknya }\end{array}$ & $\begin{array}{l}\text { Objek tangan } \\
\text { pada game } \\
\text { mengikuti } \\
\text { gerakan } \\
\text { tangan } \\
\text { pemain }\end{array}$ & $\begin{array}{l}\text { Objek } \\
\text { tangan pada } \\
\text { game } \\
\text { mampu } \\
\text { mengikuti } \\
\text { gerakan } \\
\text { tangan } \\
\text { pemain }\end{array}$ & Valid \\
\hline $\begin{array}{l}\text { Mengepal- } \\
\text { kepalkan } \\
\text { tangan }\end{array}$ & $\begin{array}{l}\text { Objek tangan } \\
\text { pada game } \\
\text { mengikuti } \\
\text { gerakan } \\
\text { tangan } \\
\text { pemain }\end{array}$ & $\begin{array}{l}\text { Objek } \\
\text { tangan pada } \\
\text { game } \\
\text { mampu } \\
\text { mengikuti } \\
\text { gerakan } \\
\text { tangan } \\
\text { pemain }\end{array}$ & Valid \\
\hline $\begin{array}{l}\text { Meletakkan } \\
\text { kedua tangan } \\
\text { di atas sensor }\end{array}$ & $\begin{array}{l}\text { Muncul } \\
\text { kedua objek } \\
\text { tangan pada } \\
\text { game }\end{array}$ & $\begin{array}{l}\text { Kedua } \\
\text { tangan } \\
\text { terdeteksi } \\
\text { oleh game }\end{array}$ & valid \\
\hline
\end{tabular}


Berdasarkan hasil pengujian, game yang dikembangkan mampu menunjukkan hasil yang sesuai pada semua scenario pengujian. Sensor LMC mampu mendeteksi tangan pasien dan gerakannya. Objek pada game juga dapat bergerak mengikuti gerakan pasien yang ditangkap oleh sensor LMC.

2) Pengujian interaksi pemain dengan game: Pengujian interaksi pemain dengan game dapat dilihat pada tabel III.

TABEL III

PENGUJIAN INTERAKSI PEMAIN

\begin{tabular}{|c|c|c|c|}
\hline $\begin{array}{l}\text { Aktivitas } \\
\text { pengujian }\end{array}$ & $\begin{array}{l}\text { Respon yang } \\
\text { diharapkan }\end{array}$ & $\begin{array}{l}\text { Hasil } \\
\text { pengujian }\end{array}$ & Kesimpulan \\
\hline \begin{tabular}{ll}
\multicolumn{2}{l}{ Mengambil } \\
objek & yang \\
ada & pada \\
game &
\end{tabular} & $\begin{array}{l}\text { Objek yang ada } \\
\text { pada game } \\
\text { bergerak } \\
\text { dengan cosuai } \\
\text { pemain }\end{array}$ & $\begin{array}{l}\text { Objek pada } \\
\text { game dapat } \\
\text { digerakkan } \\
\text { oleh pemain } \\
\text { dengan sensor }\end{array}$ & Valid \\
\hline
\end{tabular}

Berdasarkan hasil pengujian skenario interaksi pemain dengan game, dapat disimpulkan bahwa pemain mampu beriteraksi dengan game dengan lancar. Setiap objek mampu merespon skenario interaksi pemain dengan sesuai.

\section{KESIMPULAN}

Berdasarkan hasil dari penelitian, maka dapat disimpulkan bahwa pembuatan alat bantu terapi rehabilitasi otot tangan dapat dikembangkan dengan tahapan identifikasi masalah, analisis kebutuhan, perancangan alat bantu terapi, implementasi, dan pengujian. Alat bantu terapi rehabilitasi otot tangan bisa dikembangkan dalam bentuk game dengan menggunakan sensor LMC sebagai input dan kontrol pasien terhadap game.

Teknologi dapat digunakan sebagai alat bantu terapi rehabilitasi otot tangan dengan mengintegrasikan metode terapi dengan bantuan teknologi. Salah satu bentuk teknologi yang dapat digunakan yaitu game dengan sensor LMC sebagai alat input dan kontrol. Faktor yang perlu diperhatikan yaitu: 1)Sensitivitas alat input yaitu sensor LMC; 2)Metode gerakan terapi yang digunakan untuk merancang gameplay.

Beberapa hal dapat dikembangkan berdasarkan penelitian ini diantaranya:

1. Dapat dikembangkan penelitian untuk membuat desain model 3 dimensi untuk objek dalam game

2. Dapat dikembangkan penelitian untuk membuat pasien dan dokter dapat saling berinteraksi dalam game

3. Dapat dikembangkan penelitian untuk mengidentifikasi tremor pasien dengan menganalisis data posisi roll, yaw, pitch dari tangan pasien yang sudah disimpan oleh game.

\section{UCAPAN TERIMA KASIH / ACKNOWLEDGMENT}

Terima kasih kepada Universitas AMIKOM Yogyakarta yang telah mendukung penelitian ini dalam skema penelitian internal hibah pemula 2019-2.

\section{REFERENSI}

Z. Liu, Y. Zhang, P. P. Rau, and P. Choe, "Leap-Motion Based Online Interactive System for Hand Rehabilitation," 2015, vol. 9181, no. August, doi: 10.1007/978-3-319-20934-0. S. Ameur, A. Ben Khalifa, and M. S. Bouhlel, "A comprehensive leap motion database for hand gesture recognition," 2016 7th Int. Conf. Sci. Electron. Technol. Inf. Telecommun. SETIT 2016, no. December, pp. 514-519, 2017, doi: 10.1109/SETIT.2016.7939924

[3] E. D. Oña, C. Balaguer, R. Cano-De La Cuerda, S. ColladoVázquez, and A. Jardón, "Effectiveness of serious games for leap motion on the functionality of the upper limb in Parkinson's disease: A feasibility study," Comput. Intell. Neurosci., vol. 2018, 2018, doi: 10.1155/2018/7148427

[4] M. Alimanova et al., "Gamification of hand rehabilitation process using virtual reality tools: Using leap motion for hand rehabilitation," Proc. - 2017 1st IEEE Int. Conf. Robot. Comput. IRC 2017, pp. 336-339, 2017, doi: 10.1109/IRC.2017.76.

[5] A. Mckenzie, "Free-Hand Interaction with Leap Motion," CHI, pp. 1663-1668, 2014.

[6] A. Manolova, "Application for Hand Rehabilitation Using Leap Motion Sensor Based on a Gamification Approach Application for Hand Rehabilitation Using Leap Motion Sensor Based on a Gamification Approach," Int. J. Adv. Res. Sci. Eng., vol. 5, no. February, pp. 61-69, 2016.

[7] F. Setiawan Daldiri, W. N. Khotimah, and D. Herumurti, "Rancang Bangun Aplikasi Terapi Pascastroke untuk Latihan Pergerakan Jari Tangan dengan Menggunakan Leap Motion Controller," J. Tek. ITS, vol. 6, no. 2, pp. 436-439, 2017, doi: 10.12962/j23373539.v6i2.23753.

[8] I. Afyouni, A. M. Qamar, S. O. Hussain, F. U. Rehman, B. Sadiq, and A. Murad," "Motion-based serious games for hand assistive rehabilitation," Int. Conf. Intell. User Interfaces, Proc. IUI, pp. 133-136, 2017, doi: 10.1145/3030024.3040977.

[9] M. Madsen, R. el Kaliouby, M. Eckhardt, M. E. Hoque, M. S Goodwin, and R. Picard, "Lessons from participatory design with adolescents on the autism spectrum," in CHI 2009, 2009, pp. 3835-3840.

[10] W. L. Lee et al., "Objective evaluation of bradykinesia in Parkinson's disease using an inexpensive marker-less motion tracking system," Physiol. Meas., vol. 40, no. 1, 2019, doi: 10.1088/1361-6579/aafef2.

[11] F. Nainggolan, B. Siregar, and F. Fahmi, "User Experience in Excavator Simulator using Leap Motion Controller in Virtual Reality Environment User Experience in Excavator Simulator using Leap Motion Controller in Virtual Reality Environment," J. Phys. Conf. Ser., 2020, doi: 10.1088/17426596/1566/1/012093

[12] C. J. Kincaid, "Frequency response of the Leap Motion Controller and its suitability for measuring tremor," 2018.

[13] H. R. Fazeli, P. Stief, J. Dantan, A. Etienne, and A. Siadat, "A Virtual Environment for Hand Motion Analysis," Procedia CIRP, vol. 78, pp. 127-132, 2018, doi: 10.1016/j.procir.2018.09.060.

[14] V. Shah, M. Cuen, T. Mcdaniel, and R. Tadayon, "A RhythmBased Serious Game for Fine Motor Rehabilitation Using Leap Motion," 2019

[15] R. Hunicke, M. Leblanc, and R. Zubek, "MDA : A Formal Approach to Game Design and Game Research,” 2004 